\title{
MEMBANGUN KEMANDIRIAN MASYARAKAT DESA DALAM PENYELENGGARAAN JENAZAH
}

\author{
M. Dahlan R \\ Pendidikan Agama Islam, Universitas Ibn Khaldun Bogor, Indonesia \\ dahlan@uika-bogor.ac.id
}

\begin{abstract}
ABSTRAK
Abstrak: Tujuan yang ingin dicapai dari kegiatan ini yakni (1) meningkatkan pengetahuan akan kewajiban dalam mengurus jenazah, (2) meningkatkan kesadaran dan keterampilan masyarakat untuk menangani jenazah yang ada di kampung mereka, (3) meningkatkan kesadaran untuk mandiri dan tidak bergantung kepada masyarakat lain dalam permasalahan yang terjadi sehingga terbangun kemandirian desa. Metode yang digunakan dalam pengabdian masyarakat ini adalah metode diskusi dan praktek secara langsung dengan menjadikan relawan sebagai objek pelatihan terhadap 35 orang masyarakat kampung Kebon Teh Angsana Bogor dengan 2 tahapan. Pertama, sosialisasi secara pengetahuan dan diskusi terkait dengan pemahaman pengurusan jenazah. Kedua, melaksanakan praktek memandikan dan mengkafankan jenazah. Hasil dari kegiatan ini menunjukan 25 orang peserta setara dengan 70\% mampu menjelaskan dan mempraktekkan perawatan jenazah secara benar dan mereka merasa cukup puas dan siap untuk melakukan pengurusan jenazah.
\end{abstract}

Kata kunci: Kemandirian Masyarakat; Kewajiban Manusia; Perawatan Jenazah

\begin{abstract}
The purpose of this activity is (1) to increase knowledge of the obligation to take care of the body, (2) to raise awareness and skills of society to deal with the body in their village, (3) Raise awareness to Independent and not dependent on the other community in the problems that arise to awaken the independence of the village. This method used in community service is a method of discussion and practice directly by making volunteers as the object of training on 35 people in the village of Kebon Teh Angsana Bogor with two stages. First, knowledge and discussion related to the understanding of body management. Second, implement the practice of bathing and administering the body. The result of this activity shows 25 participants equal to $70 \%$ able to explain and practice the care of the body correctly, and they feel quite satisfied and ready to do body management.
\end{abstract}

Keywords: Human Obligation; Independence of the Village Community; Corpse Care

Article History:
Received: $14-01-2020$
Revised : $15-02-2020$
Accepted: $15-02-2020$
Online : $02-03-2020$




\section{A. LATAR BELAKANG}

Jenazah dalam perspektif Islam merupakan bagian dari manusia yang sudah tidak memiliki nyawa atau meninggal, karena setiap manusia pasti akan mati sebagaimana firman Allah dalam surat al Ankabut ayat 57; "Tiap-tiap yang bernyawa akan merasakan mati. Kemudian hanya kepada Kami kamu dikembalikan". Ayat ini menjelaskan bahwa setiap yang hidup pasti akan mengalami kematian termasuk di dalamnya manusia. Manusia sebagai makhluk ciptaan Allah sangat istimewa jika dibadingkan dengan ciptaan lainnya (Dahlan, 2015), manusia diberikan keunggulan dan kemampuan yang tidak dimiliki oleh makluk lain, manusia memiliki perbedaan satu dengan lainnya (Miftah Syarif, 2018). Karena manusia makhluk mulia itulah kemudian manusia yang telah mati menjadi tanggung jawab manusia lainnya yang hidup untuk mengurusnya (Riyadi, 2013), hutang maupun jasadnya (Rasjid, 2017).

Mati merupakan hilangnya nyawa dalam diri seseorang (Latif, 2016). Kejadian hilangnya nyawa dari jasad inilah yang dikenal dengan kematian, kematian merupakan putusnya jiwa dan raga serta hubungan keduanya (Murtiningsih, 2013). Meskipun perpisahan keduanya hanya sementara (Karim, 2015). Kematian akan selalu mengintai pada manusia kapanpun dan bagaimanapun kondisinya, karna kematian merupakan sunnatullah yang telah ditetapkan dalam keputusannya, maka tidaklah ada seorangpun yang akan mengalami kemunduran atau keterlambatan dari kematian, ia akan selalu datang siap maupun tidak siap. Sebagaimana firman Allah swt dalam surat al-Jum'ah ayat 8: "Katakanlah. Sesungguhnya kematian yang kamu lari daripadanya, maka sesungguhnya kematian itu akan menemui kamu, kemudian kamu akan dikembalikan kepada (Allah), yang mengetahui yang ghaib dan yang nyata, lalu Dia beritakan kepadamu apa yang telah kamu kerjakan".

Manusia yang yang telah meninggal menjadi tanggung jawab yang hidup kerabat dekat maupun kerabat jauh (Nurdin Z. , 2016). Bagi muslim mengurus jenazah menjadi kewajiban bersama yang dikenal dengan fardhu kipayah, fardhu kipayah merupakan kewajiban secara bersama-sama (Fauzan, 2014), artinya kewajiban menjadi gugur jika telah dikerjakan oleh segelintir orang, namun menjadi masalah bersama jika tidak ada satupun yang megerjakan, berbeda dengan kewajiban individu yang menjadi masalah adalah indvidunya sendiri jika tidak dikerjakan tugasnya (Muslihah Mazlal, 2016). Kewajiban orang hidup pada jenazah (Mokhtar, 2013),; Pertama, Memandikan jenazah merupakan proses penghilangan terhadap kotoran yang terdapat pada jenazah, proses ini merupakan bagian tanggung jawab yang hidup kepada jenazah agar fisik jenazah dalam keadaan bersih dan tidak ada satupun kotoran yang masih melekat pada tubuhnya, maka memandikan jenazah harus betul-betul dikerjakan secara mendetail oleh orang yang mengerti sehingga tidak lagi ada yang tersisa dari kotoran (Suwito, 2015), oleh karenanya yang paling berhak memandikan adalah keluarga terdekatnya agar tidak ada rasa canggung dalam proses memandikannya, hal ini sesuai dengan sabda Nabi SAW dari Aisyah r.a.

Rasullah Saw, bersabda,"barang siapa memandikan jenazah dan dijaganya kepercayaan, tidak dibukakannya kepada orang lain apa-apa yang dilihat pada jenazah itu, maka bersihlah ia dari segala dosanya, seperti keadaannya 
sewaktu dilahirkan oleh ibunya”. Kata beliau lagi,“yang berhak mengepalainya keluarga yang terdekat kepada jenazah jika ia pandai memandikan jenazah. Jika ia tidak pandai, maka siapa saja yang di pandang berhak karena wara'nya atau karena amalannya" (HR. Ahmad, Hadits No 23735).

Memandikan jenazahpun tidak boleh berlebihan dalam menggunakan air, cukuplah dengan seperlunya sesuai dengan kebutuhan, jika cukup dengan satu kali bilasan maka cukuplah dengan satu kali bilasan dan harus ditempat yang agak tinggi untuk memudahkan pemandian dan menghindari dari cipratan air yang dapat mengotorinya. Pemandian terhadap jenazah dilakukan agar tiap manusia yang mati dapat menghadap dengan bersih dan suci kepada Tuhannya. Dan bagi yang memandikan tidak diperkenankan untuk menceritakan keburukan yang dilihatnya proses memandikan. Kedua, Mengkafankan, ini merupakan proses pembalutan jenazah dengan kain putih yang harus menutupi seluruh fisiknya tidak terkecuali dalam proses ini jenazah tidak boleh ada yang telihat, pembalutan jenazah dengan kain kapan menggunakan bahan secukupnya 3 atau 5 helai kain sudahlah cukup yang penting tidak sampai anggota tubuh terlihat dan tidak berlebihan, meskipun dalam beberapa daerah ada yang menggunakan sampai 7 atau 9 helai kain kafan. Kain kapan yang dianjurkan adalah kain kapan yang bersih dan putih warnanya (Sabiq, 2013). Ketiga, menyolatkan, menjadi kewajiban bersama menshalatkan jenazah setelah jenazah dalam keadaan suci atau setelah dimandikan dengan seorang imam sebagai pemimpinnya disunnahkan dibuat tiga baris berderat ke belakang, dengan empat kali takbir tanpa ruku dan sujud. Shalat jenazah yang dilakukan oleh ratusan orang akan mampu memberikan syafaat bagi si mayit sebagaimana Nabi SAW bersabda:

"Jika seorang muslim wafat kemudian di shalatkan oleh lebih dari seratus muslim, maka doa yang dipanjatkan oleh mereka akan memberikan syafa'at bagi si mayit ( HR. Muslim).

Keempat, mengkuburkan menjadi kewajiban bersama yang terakhir pada mayit, mengkuburkan jenazah merupakan bagian akhir dari proses pengurusan jenazah, dibuatkan liang lahat dengan ukuran secukupnya bagi jenazah, tidak terlalu lebar dan panjang akan tetapi tidak menyulitkan bagi yang menguburkan jenazah, dengan itu maka sudah cukup ukuran jenazah, pada umumnya para penggali kubur akan mengukur jenazah agar tidak terlalu panjang ketika dilakukan penggalian, sementara kedalamnnya disesuaikan dengan kepadatan tanah yang dijadikan kuburan, pada umumnya antara $100 \mathrm{~cm}$ sampai dengan $150 \mathrm{~cm}$, hal ini sangat penting agar tidak terjadi hal-hal yang tidak dinginkan setelah dilakukan penguburan, karena bisa jadi kuburan yang dangkal akan memancing binatang darat datang melakukan perusakan terhadap kuburan dan mengeluarkan jenazah dari liang lahat.

Keempat kewajiban ini menjadi tanggung jawab muslim yang hidup, namun dalam kenyataannya tidak sedikit orang Islam yang tidak faham dalam menangani jenazah (Yasnel, 2018), hal ini banyak disebabkan karena ketidaktahuan dan ketidakberaniaan dalam menghadapi manusia yang telah kaku mayat). Hal ini terjadi juga di daerah Cibeber Dua, sebuah kampung yang teretak di kecamatan Lewiliang, Masyarakat pada 
umumnya mengandalkan amil untuk melakukan pengurusan jenazah, hal ini menjadi kesulitan tersendiri karena amil yang ada sangat jauh dan tidak berada dalam satu kampung, sehingga jenazah terkadang menunggu berjam-jam kedatangan amil untuk mengurusnya.

Lokasi pengabdian masyarakat ini berada di Kampung Kebon Teh Angsana Desa Cibeber Dua Kec. Lewiliang Bogor. Masyarakat yang ada di sana tidak berani melakukan perawatan terhadap jenazah disebabkan karena ketidaktahuan dan kurang beraninya dalam menghadapi jenazah, sehingga di saat ada yang mengalami kematian akan selalu menunggu amil dari kampung sebelah untuk melakukan pengurusannya, masyarakat yang ada lebih banyak membantu menggali kuburan jika dibandingkan dengan mengurus jenazah, kondisi inilah yang mendorong dilaksanakannya pelatihan pengurusan jenazah pada masyarakat Cibeber dua Kecamatan Lewiliang Kabupaten Bogor.

Adapun tujuan kegiatan ini yakni (1) meningkatkan pengetahuan akan kewajiban dalam mengurus jenazah, (2) meningkatkan kesadaran dan keterampilan masyarakat untuk menangani jenazah yang ada di kampung mereka, (3) meningkatkan kesadaran untuk mandiri dan tidak bergantung kepada masyarakat lain dalam permasalahan yang terjadi sehingga terbangun kemandirian desa.

\section{B. METODE PELAKSANAAN}

Pelaksaaan pengabdian dilaksanakan di kampung Kebon Teh Angsana Desa Cibeber Dua Kec. Lewiliang, melibatkan tokoh dan pemuka agama dengan jumlah peserta 50 orang; 20 laki-laki dan 30 wanita, menggunakan metode diskusi dan praktek secara langsung dengan menjadikan relawan sebagai objek pelatihan dan nara sumber M. Dahlan R, dilaksanakan dalam satu hari dengan 2 tahapan, tahapan pertama sosialisasi secara pengetahuan dan diskusi terkait dengan pemahaman pengurusan jenazah yang meliputi; a) sikap terhadap jenazah, b) cara memandikan jenazah, c) cara mengkapankan jenazah, dan d) cara menguburkan jenazah. Kedua, melaksanakan praktek memandikan dan mengkafankan jenazah beberapa kali sehingga didapatkan pemahaman dan kemampuan untuk mempraktekan secara langsung. Untuk mengukur kemampuan dan pemahaman maka diberikan pre test dan post test untuk mengukur kemampuan penanganan jenazah bagi peserta. Pre test diberikan sebelum acara dimulai dengan tanya jawab seputar pengetahuan dan cara merawat jenazah dengan indikator mampu menerangkan dan mempraktekan, dari jawaban 35 peserta 5 orang yang mampu menerangkan dan 30 orang sisanya tidak tahu sama sekali, Selesai acara dilakukan post-test dengan indikator yang sama dan dilakukan testimoni kepada peserta sebagai tolak ukur pelaksanaan kegiatan.

\section{HASIL DAN PEMBAHASAN}

Pemecahan masalah yang dapat dilakukan yaitu memberikan pengetahuan, pemahaman, dan pelatihan mengenai penanganan jenazah. 
Setelah dilakukan diskusi dengan Kepala Desa Cibeber Dua ditentukanlah kp. Kebon The Agsana sebagai tempat pelaksanaan, maka diskusipun dilanjutkan dengan ketua Rukun tetangga di kp. Kebon Teh Angsana. Peningkatan pengetahuan dan kewajiban terhadap jenazah diberikan dalam bentuk ceramah dan tanya jawab sejak seseorang menghembuskan nafas, dari hasil wawancara mayoritas penduduk kp Kebon Teh Angsana dan umumnya Cibeber Dua tidak tahu bangaimana caranya mengurus jenazah, hal ini menjadi dasar dalam sosialisasi pengurusan jenazah sehingga tidak hanya dalam konsep penyampaian materi namun lebih dari itu setiap apa yang disampaikan dilakukan tanya jawab, sehingga masyarakat lebih mengerti secara mendatail terkait cara penanganan jenazah. Dalam ceramah dan diskusi ini disampaikan hal-hal yang harus dikerjakan sejak seseorang divonis meninggal, yaitu dengan melakukan pemejaman terhadap matanya dengan cara mengusap dengan telapak tangan dari atas kepala sampai ke dagu, kemudian mulutnya dirapatkan dengan didorong dagunya atau diikat dengan menggunakan tali yang terbuat dari kain atau sejenisnya. Kemudian jenazah dibaringkan sesuai dengan sunnah dengan meletakan arah kiblat ada di sebelah kanannya, namun jika tidak memungkinkan maka jenazah dibaringkan sesuai dengan kondisi tempat.

Pemberian materi mengenai jenazah juga disampaikan hukumnya dan apa konsekwensinya jika jenazah tidak ada yang menangani, baik secara medis maupun secara hukum agama; secara medis jenazah yang dibiarkan akan semakin membusuk dan akan menyebabkan tempat berbagai ribuan virus berada dan ini sangat membahayakan masyarakat sekitarnya, sementara dari hukum agama membiarkan jenazah menjadi dosa bersamasama, maka perlu ada orang yang mampu untuk menggugurkan dosa itu dengan menangani jenazah yang ada di sekitar mereka. Dalam hal ini setiap pembahasan diberikan dan langsung dilakukan tanya jawab sehingga penyampaian materi menjadi hidup dan tidak menjenuhkan, proses pemberian materi inipun berusaha untuk menggali tingkat pemahaman masyarakat dengan melakukan pertanyaan sebelum bagianbagian pembahasan dibahas maupun setelahnya, hal ini dilalukan untuk mengukur sejauh mana pemahaman materi dapat diserap dan dipahami oleh masyarakat sehingga pemahaman mereka semakin bertambah.

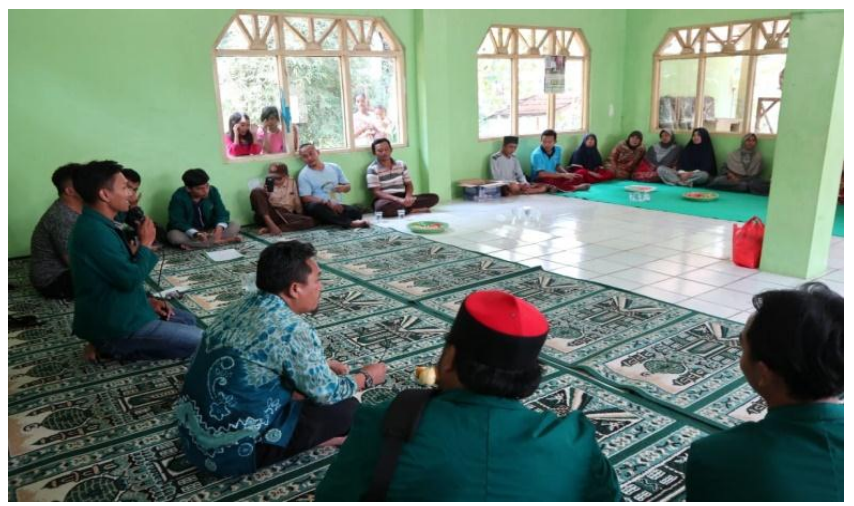

Gambar 1. Kegiatan Pemberian Pengetahuan dan Tanya Jawab

Gambar 1 merupakan tahapan sosialisasi guna memberikan kesadaran dan kemandirian dalam penanganan jenazah dilakukan praktek secara langsung memandikan dan mengkapankan jenazah, dalam hal 
memandikan diberikan contoh secara langsung dengan relawan sebagai alat peraganya namun dalam prakteknya tidak menggunakan air, hanya mengerakan gayung sebagai simbol tempat pengguyuran air, proses pemandian dilakukan dihadapan para peserta dimulai dengan penyiapan tempat memandikan dengan menghadapkan kea rah kiblat jika memungkin dan diberikan penutup disekitar tempat memandikan agar tidak semua orang dapat melihatnya. Kemudian disiapkan air yang dapat dicampur dengan daun bidara secukupnya dan dapat mengalir kearah aliran air atau dilakukan pembuangan air pemandian jenazah ke lubang yang telah dibuat, selanjutnya jenazah diangkat dan diletakan di atas tempat yang telah disediakan berupa bak keranda atau batang pohon pisang yang telah dibuat, dibuka baju jenazah dengan mengguntingnya dan tetap dalam keadaan aurat tertutup. Setelah pakaian terlepas dari jenazah maka proses penyiraman mulai dilakukan mulai dari ujung kaki sampai kepala sedikit demi sedikit dan diberikan pembersihan dengan sabun dan dibersihkan seluruh kotoran yang ada pada jenazah; kuku maupun kuping, selesai pemandian dilakukan proses pengeringan dengan menggunakan kain kapan sebagai handuknya. Secara mendetail hal ini diulang berkalikali sehingga peserta merasa cukup mengerti untuk mempraktekan di kemudian hari. Selanjutnya jenazah diangkat dan dibawa keatas kain kapan yang telah disiapkan; 5-7 helai kain kapan terdiri dari 3 helai kain kapan di letakan memanjang di bawah dan diserongkan membesar ke atas, 1 helai kain kapan dengan panjang setengah dari ukuran 3 helai yang pertama, diletakan di atas tumpukan pertama ke arah bawah, dan satu helai kain kapan berukuran 2 meter atau lebih dilipat menjadi 2 diberikan corak lubang di tengah-tengahnya dan diletakan di tiga perempat 3 kain pertama sebelah atas, sementara untuk kepala disiapkan kain 0,5 meter dan dibuatkan segitiga diletakan di atas 3 kain pertama paling atas, untuk wanita sudut segitiga berada di bawah sementara bagi pria bentuk segitiga ada di atasnya, kain kapan yang telah disiapkan ditaburi dengan kapur barus atau diberikan wewangian secukupnya. Setelah itu kemudian jenazah diletakan di atasnya dan dibungkus dimulai dari sebelah kanan dan diikuti sebelah kiri serta diikat dengan tali yang telah disiapkan di bawah kain kapan, pada umumnya tali itu terletak di bawah telapak kaki, di betis,di dada dan di atas kepala. Setelah diikat maka jenazah sudah siap untuk disholatkan dan dikuburkan.

Memberikan pembungkus terhadap jenazah yang telah dimandikan, diberikan secara demontrasi dan praktek tahapan demi tahapan hingga sempurna, dalam praktek ini instruktur memberikan contoh kemudian dipraktekkan oleh peserta yang lain sebagai perwakilan dan dilakukan secara berulang-ulang sampai mereka memahami secara sempurna. Adapun proses praktik langsung terlihat pada Gambar 2 berikut. 


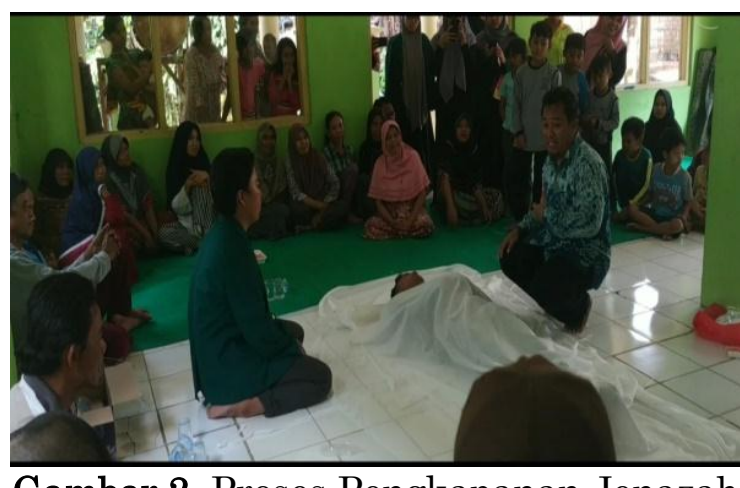

Gambar 2. Proses Pengkapanan Jenazah

Pada akhir acara dilaksanakan tanya jawab kepada seluruh peserta dari 35 peserta didapatkan 25 orang yang mampu menjelaskan dan mempraktekkan perawatan jenazah secara benar, sisanya masih merasa ragu-ragu dan belum faham secara mendalam. testimoni juga dilakukan secara langsung dengan beberapa peserta terkait sosialisasi dan praktek penyelengara jenazah, hasilnya didapatkan bahwa mereka merasa cukup puas dan siap untuk melakukan pengurusan jenazah khususnya di kampung mereka jika terjadi kematian yang menimpa salah seorang diantara mereka.

\section{SIMPULAN DAN SARAN}

Sambutan warga terhadap kegiatan ini begitu antusias karena mereka merasa selama ini tidak pernah ada yang mengajarkan sampai mendetail dan praktek, Dengan adanya pemberdayaan masyarakat Cibeber Dua khususnya kp. Kebon Teh Angsana dalam penyelenggaraan jenazah melalui pelatihan dapat meningkatkan pengetahuan dan keberanian masyarakat dalam menangani jenazah dan terbangunnya kemandirian masyarakat desa, Kesanggupan mereka untuk menyelesaikan permasalahan kematian merupakan bagian dari tanggung jawab sebagai makhluk hidup. merekapun sangat berharap banyak yang melakukan pelatihan-pelatihan semacam ini dalam berbagai hal yang mereka butuhkan. Masyarakat sangat terbuka dan membutuhkan uluran tangan para ilmuan atau akademisi untuk menambah pengetahuan dan kemampuan masyarakat dalam berbagai hal. Kemandirian masyarakat desa akan terbangun ketika keilmuan dan pengetahuan mereka memiliki kesamaan meskipun tingkatannya bereda-beda.

Adapun saran yang bisa diberikan adalah; kemandirian masyarakat desa terbagun karena adanya kerjasama dan gotong royong dalam mengerjakan sesuatu, hal ini terjadi manakala mereka memiliki pengetahuan yang sama dan seimbang, peran tokoh masyarkat dan ketua Rukun Tetangga serta pengurus masjid sangat diharapkan masyarakat untuk menjalin kerjasama dengan pihak-pihak terkait dalam meningkatkan pemahaman dan kemampuan masyarakat desa, sudah saatnya masyarakat mandiri dengan menangani segala permasalahan yang ada secara mandiri dan bersama-sama tanpa menunggu bantuan masyarakat lain. 


\section{UCAPAN TERIMA KASIH}

Terimakasih kami haturkan kepada bapak Camat Lewiliang dan kepal desa Cibeber dua Bapak Yudi yang telah mengizinkan untuk mengadakan pelatihan ini, terimakasih pula kami sampaikan pada DKM masjid Nurul Huda dan ketua RT Kebun Teh Angsana bapak Asep yang telah mengikutsertakan masyarakatnya dalam membangun kemandirian desa melalui penanganan jenazah, dan seluruh masyarakat Cibeber Dua. Semoga apa yang telah dilaksankan dapat bermanfaat buat kemandirian masyarakat desa.

\section{DAFTAR RUJUKAN}

Mokhtar, S. (2013). Pendidikan Agama Islam XI. Surakarta: Pustaka Firdaus Utama.

Sabiq, S. (2013). Fikih Sunnah. Jakarta: Tirta Abadi Gemilang.

Murtiningsih. (2013). Hakikat Kematian Menurut Tinjauan Tasawuf. Jurnal Intizar, 19, 323-342.

Karim, A. (2015, Juni). Makna Kematian dalam Perspektif Tasawuf. Jurnal Esoterik, 1, 21-46.

Yasnel. (2018, April). Refleksi Sosial Penyelenggaraan Jenazah bagi Mahasiswa. Jurnal El-Ibtidaiy: Journal of Primary Education, 1, 7289.

Nurdin, Z. (2016, Januari-April). Problematika Penyelenggaraan Jenazah di Kota Bengkulu. Jurnal Manhaj, 1, 79-88.

Riyadi, A. (2013). Upaya Pemberdayaan dan Peningkatan Keterampilan Pemulasaraan Jenazah di Wilayah Kec. Mijen Kota Semarang. Jurnal Dimas, 13(2), 201-219.

Latif, U. (2016). Konsep Mati dan Hidup Dalam Islam. Jurnal Al Bayan, $22(34), 27-38$.

Nurdin, Z. (2016, Januari-April). Problematika Penyelengaraan Jenazah di Kota Bengkulu. Jurnal Manhaj, 4(1), 80-88.

Suwito, A. S. (2015, Desember). Tradisi dan Ritual Kematian Wong Islam Jawa. Jurnal Ibda', 13(2), 197-216.

Dahlan, M. (2015). Membangun Manusia Berkualitas melalui Penddikan. Fikrah, 8(1), 55-71.

Rasjid, S. (2017). Fiqih Islam. Bandung: Sinar Baru Alexindo.

Analisis Tingkat Pengetahuan Masyarakat Desa Sei-Petai terhadap Penyelenggaraan Jenazah Kec. Kampar Kiri Hilr Kab. Kampar. (2018). Jurnal Al-Hkmah, 15(1), 96-110.

Miftah Syarif, A. A. (2018). Analisis Tingkat Pengetahuan Masyarakat Desa Sei-Petai terhadap Penyelenggaraan Jenazah Kec. Kampar Kiri Hilir Kab. Kampar. Jurnal Al-Hikmah, 15(1), 96-110.

Muslihah Mazlal, M. A. (2016). Fardhu 'Ain Sebagai Kerangka Pembentukan Disiplin Pelajar di Institusi Pendidikan Islam. Jurnal 'Ulwan, 1(1), 59-73.

Fauzan. (2014, Januari). Kurikulum Pendidikan Islam dalam Perspektif Tokoh Pendidikan Islam. Jurnal Ilmiah Peuradeun, 2(1), 93-105. 